\title{
Product development strategy with quality function deployment approach: A case study in au- tomotive battery
}

\author{
Heru Darmawan ${ }^{a *}$, Humiras Hardi Purba ${ }^{a}$, Rahmad Rezeki ${ }^{a}$, Nurwahid Hidayat ${ }^{\text {a }}$, Aghib Ri- \\ taldi Siregar $^{a}$, Fitri Retna ${ }^{a}$ and Siti Aisyah ${ }^{b}$
}

${ }^{a}$ Mercu Buana University, Jakarta, 11650, Indonesia

${ }^{b}$ Industrial Engineering and Management Program, College of Industrial Management, Ministry of Industry-Republic of Indonesia

\section{CHRO N I C LE ABSTRACT}

Article history:

Received: July 24, 2017

Received in revised format: $\mathrm{Au}-$ gust 6, 2017

Accepted: August 14, 2017

Available online:

August 14, 2017

Keywords:

Customer satisfaction

Quality function deployment

Automotive

Battery

\begin{abstract}
Customer satisfaction is one of the main factors in determining the competitiveness of every industry. Along with the technological advances, it will impact on the increasingly intense competition in the business of providing great opportunities to the consumer to find a quality product at competitive rates. The purpose of this study is to develop the quality of automotive battery products that meet consumer needs by using Quality Function Deployment (QFD) method. The application is then analyzed and its results produced a proposal for product development according to the weight and priority development on product attributes that are considered important by customers. There are two main priorities that are most desired by customers, among others for improving the quality of products maintenance free battery in automotive battery industry with quality function deployment according to consumers. Consumers need a car battery with a good durability and great performance, low price, and environment friendly features, which can be achieved by using absorbent glass mat and expanded machine technology. Based on relative weight in House of Quality, Absorbent Glass Mat receives the highest percentage of technical priority that is equal to $31 \%$ whereas technology expanded gets the second highest percentage of technical priority that is equal to $19 \%$. It means that both technologies are more important to develop this product. Therefore, the maintenance free battery products are expected to be attractive for consumers and extensive marketing.
\end{abstract}

\section{Introduction}

The level of car sales in the last 2 years of 2016 and 2017 has increased very well. As it is reported by the Association of Indonesian Automotive Industries (Gaikindo), the number of car sales in 2016 rose by $4.5 \%$ compared to 2015 of 1.06 million units. Then, in the first quarter of 2017 Gaikindo launching car sales growth from the year 2016 of 5.96\%. Increasing sales of this car will encourage increased sales of car batteries too. Increasing demand for car batteries coupled with increased auto sales poses challenges for car battery manufacturers to boost their competitiveness of creating long-lasting, competitive car battery products.

* Corresponding author.

E-mail address: herudarmawan100787@gmail.com (H. Darmawan) 
The most complaints of customers to existing car batteries relate to the short durability of approximately 1-1.5 years usage. It is the hot temperature occurs in the engine room that shortens the battery life. This condition is also caused by the fact that the car's design now has a relatively narrow engine space so that the temperature in the engine room becomes higher and the release of heat in the engine room becomes longer.

Besides, road conditions in the cities of Indonesia where the daily congestion happens is getting worse today and it exacerbates the temperature conditions around the battery. Finally, it makes the battery condition often stressful. Technological developments that are applied in today's cars make the car loaded with electronic devices ranging from engines, transmissions to security devices that require a greater supply of electricity. Based on the reason, many of automotive battery products now have another alternative technology relating to silver inside on the battery to make long life time battery (Fouache et al. 1999). In addition to the issues above, the environmental issues are of great concern in car battery products. Most current car batteries are still composed of less environmentally friendly chemicals. It is a challenge in the future to create an environmentally friendly car battery. Based on these conditions, the development of existing battery products must be the batteries that have longer lasting life in accordance with the current design conditions and current environmental conditions as well as environmentally friendly battery products (Scrosati and Garche, 2010).

Nowadays, the ability to present new products to the market in a fast way while satisfying customer expectations is getting more and more important for the entire customer focused firms. The success of every business is more and more customer driven, so the company needs to develop a customer's delight in order to bring the profit and high productivity (Shen et al., 2001). The concept of Quality Function Deployment (QFD) for new product development under the umbrella of Total Quality Control was developed. QFD has become the most used means by manufacturers and service industries to translate customer requirements to engineering specifications. It is a link between customers - design engineers - competitors - manufacturing. In the other hand, QFD provides insight into the entire design manufacturing operation from concept to manufacture and it can significantly improve the efficiency as production problems are resolved early in the state of the design.

The key success of new products in the market usually depends on how well they can meet customer's requirements (Hamidullah et al., 2010). Puviyarasu (2016), for example, used QFD technique in development of new modified centrifugal pump to improve customer satisfaction. The product satisfaction was evaluated by two parts groups of product users and selling agent stores. The results show that average customer satisfaction values for new modified type centrifugal pump increased compared with the current products. QFD is an effective tool for eliciting customers stated and implied requirements. Since QFD for a product will be developed through brainstorming, it brings together the talents of every employee. It is also an effective quality-planning tool (Homkhiew et al., 2012). The tool enables conversion of customer's needs into specific quality plans. This paper discusses the design of batteries that have good durability with low prices and performance capacity and cold cranking large ampere. The ultimate goal of this paper is to design and develop an existing lead acid battery based on the customer's requirement. Quality Function Deployment is a tool that can be expanded to any fast growing industry, such as the consumer electronics industry, and reduce the cost of development lead time, reduce internal decision time, turn qualitative into quantitative reasoning (Israr \& Gangele, 2014).

\section{Literature Review}

Literature provides a lot of publication regarding QFD on development of new products. In this section, some of them are presented from the previous work of researchers who have attempted application of quality function deployment to develop new products especially in product design phase. 
According to Govers (2001), QFD is a method of continuous product improvement with concern to impact on organizational learning on innovation. This method is one of the improvement tools that helps companies to achieve its high quality especially on new product development. To achieve the goal of new product, they must be observed and developed for reflecting the companies' culture and management's vision. Competition on the market requires continuous quality improvement and innovations, to discuss possible improvement of development process by QFD method for developing new product. When we study the differences between the American/Europe and Japanese approach concern regarding the position of the customer and the way of deploying quality characteristic and marketing policy we will find different issues. In United States and European, the companies' approach is more passive or reactive when facing the customer. Here the voice of customer emphasizes the expressed quality and sets the direction of the deployment. In other side, in Japanese companies, to gain the market share for the product-family concerned, most of Japanese producers are on the lookout for new target groups by focusing more on implicit and attractive quality. Quality function deployment (QFD) in application is used because of its three basic reasons: to save design time and development time of new product, to focus and concern into customer satisfaction and to improve communication at all levels of the organization (Kasim et al. 2009). According to Chan and $\mathrm{Wu}$ (2002), quality function deployment (QFD) is a technique employed to translate customer voice or customer wants into technical requirement of a product which will be developed. They conducted analysis for develop new product on functional fields of quality function deployment (QFD), applied industries and methodological development of new product. The other, Canevalli and Miguel (2008) mentioned that conceptual and empirical research of quality function deployment (QFD) can find difficulties through its application such as interpreting the customer voice and correlations between quality demand and quality characteristics of product.

Zhang (2006) has mentioned that the separator is a critical component of a battery. Its main function is to prevent physical contact of the electrodes while permitting ions to flow freely. The separator itself does not participate in any cell reactions. Nevertheless, its properties significantly determine the performance and safety of the batteries. The separator is required to be very thin and highly porous for high energy and power densities while it adversely affects the safety and cycle life of the battery as a result of the reduced mechanical strength. Relating to the same issue, Endoh (1996) has mentioned that it is well known that the performances of automotive battery are determined by the characteristics of the chosen separators. Polyethylene envelope separator area suitable for cold climates as in Europe because this product has a micro-pouros separator and give the less internal resistance in the battery and get the higher cold cranking ampere while leaf type and synthetic glass mat are more appropriate for warm and hot climates.

Today, the advance of technology separator used is Absorbent Glass Mat (AGM). AGM technology became popular in the early 1980s as a sealed lead acid battery for military aircraft, vehicles and UPS to reduce weight and improve reliability. To make the battery spill-proof, the sulfuric acid $\left(\mathrm{H}_{2} \mathrm{SO}_{4}\right)$ absorbed by a very fine fiberglass mat can be used. It enables shipment without hazardous material restrictions. The plates can be made flat to resemble a standard flooded lead acid pack in a rectangular case; they can also be wound into a cylindrical cell (Yamaguchi et al. 2000). AGM batteries look different than other battery types. They are more compact because there is no free electrolyte so that makes them more "volume efficient" because they take up less space for their energy storing capacity. Inside an AGM battery, the separators between the negative and positive plates are made of a special fiber which is resistant to heat and acid. The fiber makes the AGM battery less prone to spilling acid in that there is less liquid acid contained inside the battery. As additional, an internal safety valve is used in case if happened accidental overcharging. The safety valve opens if gas pressures inside the battery reach a critical point venting the gasses to the outside. AGM has advantage such as very low internal resistance and capable to deliver high currents on demand and offers a relatively long service life, even 
in deep cycled condition. In addition to maintenance free battery, AGM has a good electrical reliability performance and is lighter than the flooded lead acid type. In lead acid battery performance battery should be maintained by recharging every three months to prevent the buildup of sulfation. AGM batteries are less prone to sulfation and can sit in storage for longer before a charge becomes necessary (Catherino et al., 2004). The battery stands up well to low temperatures and has a low self-discharge (Thele et al., 2006).

Lead-Acid battery technology is generally deployed in any passenger vehicle. The battery are mandatory for running of standard combustion engines for automotive application. Therefore, they are often observed by a so called battery management system (BMS) (Kerley et al., 2015). AGM batteries are usually used in some modern vehicles with idle start stop system. Some modern vehicles are equipped with an elaborate energy management, which not least is due to the introduction of an intelligent battery sensor. That makes the possibility of monitoring the permanent charging status (State of Charging), ageing status (State of Health) and cold cranking capability (SOF). In vehicles that are already equipped with an intelligent battery sensor, the implementation of the requirements mentioned above is considerably easier, then the battery sensor already measures the relevant battery and operational data (Dost $\&$ Sourkounis, 2012). Hence, with the help of this data, the refresh intervals can be more easily determined as the previous history of the battery is known. A possible symbiosis for the automobile and charger manufacturers could therefore be that the BMS determines the point in time for a refresh. After that, the relevant data for the refresh charge could be sent to the external charger and based on this the charging parameters are then determined. By using this method, the charging time is optimized and the inevitable gassing and corrosion due to the refresh charge are minimized (Bui et al., 2000).

\section{Methodology}

The QFD method for development new product includes building one or more matrices known as "quality tables.". The first matrix is named the "House of Quality". It exhibits the customers' needs (voice of customers) and customer wants on the left side, and the technical response to meeting those needs along the top of House of Quality. Every section holds important data and specific to a part of the QFD analysis for development of a new product. The matrix is usually completed by a specially formed team (from the multi-disciplinary team), who follows the logical sequence suggested by the letters A to F. Nevertheless, the process is flexible and the order in which the house of quality is completed depends on the team (Delgado \& Aspinwall, 2003). According to Dawson and Askin (1999), the house of quality has been widely proposed as a method to capture and get data choice of the customer (VOC) during developing requirements for new products. The methodology has lacked a formal mechanism for trading off the customer preferences with the technical feasibility and economic reality in the market. Non-linear mathematical program can be used to determine the optimal engineering specifications during new product development as a function of engineering development, production costs and elicited customer value functions. In the sequential organizational structure, we can compare with team based organization and incorporating method such as house of quality. Based on the key findings of the firm's organizational structure and agents' incentive system, we show that the house of quality is less affected by the incentive scheme and this becomes an important factor for new product success (Natter et al. 2001).

To accomplish the goal of this product development, the house of quality of the QFD technique was chosen and employed. Three main steps carried out for the house of quality (HOQ) of QFD technique are described as follows, 


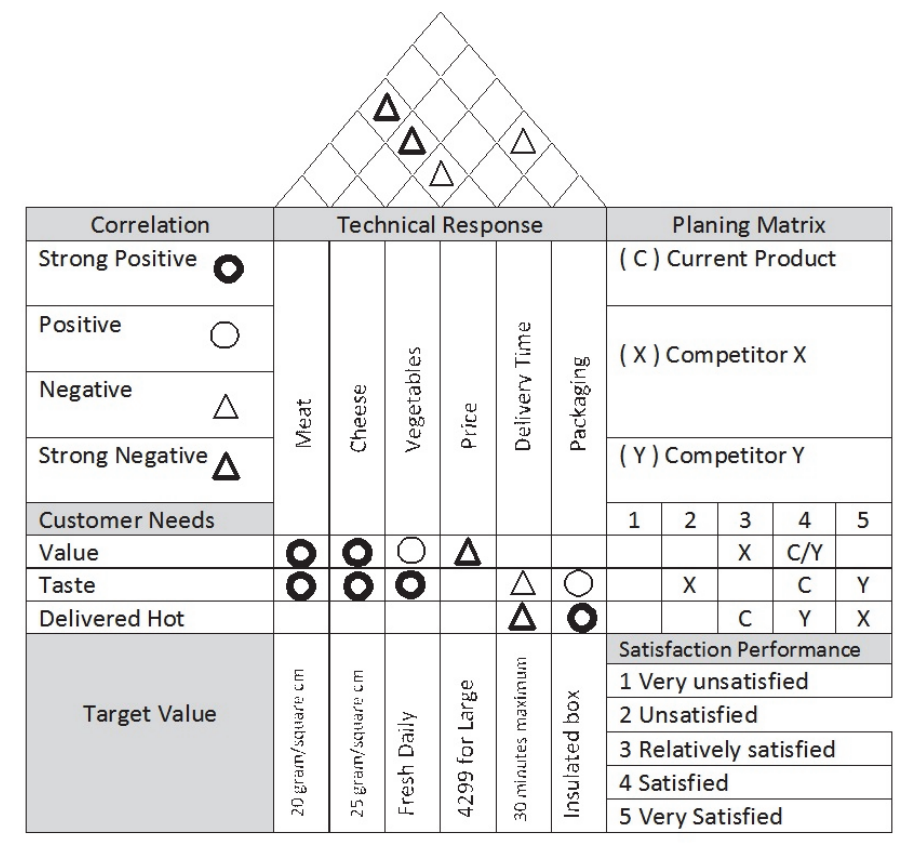

Fig. 1. The House of Quality (Sower et al. 1999)

Step 1: Voice of the customer

In order to obtain the new modified design of product, the survey was conducted for the customer in association with the product of maintenance free battery. To obtain this information, we collect data from all Indonesia dealers and some of dealers in Southeast Asia, South Asia, Australia, Europe and Africa. The purpose is to know what the voice of customer about the requirement of maintenance free product is. This primary information are gained from questions which also consist of personal ideas of each customer. From these ideas, an analysis can be done by using affinity diagram shown in Fig. 2. Islam (2005) has mentioned that the affinity diagram, which is regarded as one of the seven 'new' management tools, was used to gather a large amount of subjective data concerning an issue and subsequently classify them into several groups. One of the most important things in developing the product design by using quality function deployment is how to capture and get the true customer requirements. One of them is by using develop systematic methods, process and techniques for eliciting complete and true customer requirements from multiple perspective (Liu et al., 2001).

CUSTOMER REQUIREMENTS

\begin{tabular}{|c|}
\hline PRODUCTION ISSUE \\
\hline Cheap car batteries \\
\hline $\begin{array}{c}\text { Car battery with lifetime is still }>2 \\
\text { years }\end{array}$ \\
\hline Car battery with large capacity \\
\hline Car battery with large ampere \\
\hline $\begin{array}{c}\text { There is an electrical indicator on } \\
\text { the battery }\end{array}$ \\
\hline Battery with fast charge process \\
\hline Car battery hold vibration \\
\hline
\end{tabular}

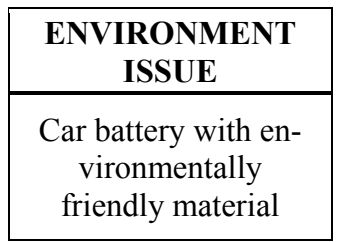

\begin{tabular}{|c|}
\hline DESIGN ISSUE \\
\hline Ease of use \\
\hline $\begin{array}{c}\text { Car batteries are the same size } \\
\text { and small }\end{array}$ \\
\hline
\end{tabular}

Fig. 2. Illustration of the affinity diagram 
Step 2: Customer requirements

After getting data from voice of the customer, based on the data collected by all Indonesia dealers and some of dealers in Southeast Asia, South Asia, Australia, Europe and Africa, the questionnaire were produced to convey the significance level of needs and level of satisfaction on current maintenance free product. The respondents took an evaluation choice on a scale from 1 to 5 , where 5 is being more important and 1 is being less important. In order to complete this task, the needs weights were multiplied by improvement ratio values, resulting in the important ranking. Customer needs or customer requirements, which belong to different categories according to how much they affect the degree of global satisfaction of a product or service, in this part must be ranked according to the customer preferences. The ranking was carried out on the basis of customer feedback obtained from the customer survey (Hamidullah et al., 2010).

\section{Step 3: Product planning matrix, or House of Quality development}

The matrix of the QFD method is called the House of Quality which is constructed to analyze and translate the customer requirements (What's) into technical requirements (How's). Partovi and Corredoira (2002) have mentioned that the basic structure of the house of quality could be presented in Fig. 1. Vairaktarakis (1999) has mentioned that the building of the first house of quality consists of 6 basic sections as explanation below:

Section 1: In this part, the customer requirement and the significant level of needs are gathered from the existing needs of customer and this information was identified through a survey with the first and the second questionnaire. Most of mentioned items were listed as the "customer requirement" (What's) (Boonyanuwat et al., 2008).

Based on the existing needs from customers, there are four items needed by the customer which are more important such as cheap price, long life time, high capacity and environmental friendly and given the score 5, other requirements such as high ampere, fast charge, anti-vibration and size of battery are given score 4, while on battery with ease of use is given score 3 and battery with electrical indicator is given score 2. All measurement based on scale 1-5 where 5 represents the most important and 1 means the less important.

Section 2: The levels of satisfaction of the case-study factory are compared with other similar industries or benchmarking with the existing companies. The main goal of satisfaction level in each customer requirement is selected from the maximum value between the value of the case-study factory and the other existing similar industries. The important ranking value for each customer requirement is determined by multiplying the improvement ratio with the significance level of needs. Competitive benchmarking is conducted to inquire on the level of importance of each requirement and in the survey form, individual customer is requested to evaluate degree of satisfaction obtained within his/her company from the use of the maintenance free product (Hamidullah et al., 2010).

In this section, we can see that to develop new product of maintenance free battery, our planned customer satisfaction rating is battery long life time with $\%$ of total weight is $14 \%$, have a larger capacity with $\%$ of total weight is $13 \%$ and cheap prize with $\%$ of total weight is $15 \%$. From this section and by considering together customer importance, improvement factor and sales point leads to an overall weighting for the need. It is very important that the publisher achieves its planned rating of 5 for accuracy.

Section 3: Technical requirement (How's) is the result of group brainstorming from various related sections in the factory including ownership and the management team, marketing, production, process 
and product design, and planning and warehouse departments (Chan \& $\mathrm{Wu}, 2002)$. It is sometimes referred to as the voice of the company.

Method of cause-effect diagram was applied to analyze the relationship between the technical requirements to meet the customer requirements. As a result, the target value of the technical requirements was set to measure and determine the direction of the main goal of improvement (Pavlov \& Dimitrov, 2001). To meet the customer requirements, there are several technical requirements such as considering the leading edge technology (to make faster charge), expanded technology (to make efficient cost production battery), automatic machine (increase quality and productivity), absorbent glass mat (to make long life time, larger capacity, cca and environment friendly), effective double seal cover (to make long life time, ease to use and environment friendly), idling start stop technology (to make long life time, larger capacity and cca especially which is used in modern vehicle), calcium alloy with silver inside (to make long life time) and sulfate stop (to make long life time).

Section 4: Rating of the relationship between the customer requirements and the technical requirements was evaluated by a group of product development team. The relationship matrix was then constructed to provide a listing of how the technical requirements represent each customer's needs on a scale of 1 , 3 , and 9. The rating scale 1 represents a slight or possible relationship, 3 represents a moderate relationship, and 9 stands for a strong relationship (Boonyanuwat et al., 2008). After we specify the rating scale of relationship between technical requirements and customer need, we can see that absorbent glass mat technology has a strong relationship with the customer requirements (long life time and good performance battery).

Section 5: Priority relationships consists of two sections, the significance levels of the absolute and the relative technical requirements. These are the measurement for the How's. The use of the significance value is to determine priorities and direction for improvements of the How's (Benner et al., 2003). Now we can determine the technical priority to meet the customer requirements. After we finished a brainstorming with the group, we can see that absorbent glass mat technology has this item and can be seen at technical priority to meet the customer requirements, $\%$ of total priority for absorbent glass mat is $31 \%$, then expanded technology has the second priority where the $\%$ of total priority is $19 \%$, then idling start stop technology has the third priority where the $\%$ of total priority is $17 \%$, then red lead technology has the fourth priority where the total priority is $11 \%$, then calcium alloy with silver inside has the fifth priority where the $\%$ of total priority is $9 \%$, then effective double sealed cover has the sixth priority where the $\%$ of total priority is $6 \%$.

Section 6: The technical correlations, assigned in the roof of the HOQ, are the result of group brainstorming and group discussion to determine the relationship between the "How's" and to show what "How's" influence each technique to meet the customer requirements (Benner et al., 2003). These indications show that technical elements affect the performance of each other's, which is represented by the sign "-" for a weak relationship and by "+" for a strong relationship (Pinta, 2002).

After we finished a brainstorming with the group to meet the technical correlations using the roof of the house of quality, we have found that there were some correlations in different components of various technologies. The technical correlation with the highest score of customer needs is battery products that have good durability with great performance and low price and environmentally friendly translated with the technical correlation between expanded plate technology and absorbent glass mat technology to meet the customer requirement. 


\section{Result and Discussion}

The product which was chosen to develop is maintenance free battery. The House of Quality of the Quality Function Deployment technique was applied to design and produce the new type of lead acid battery as shown in Fig. 3. Product development using the Quality Function Deployment method starts from the listening stage of the desire of the consumers. The needs of consumers on automotive battery products that have good durability with great performance, low prices, and environmentally friendly priority of the customer's interest and at this stage is given the highest score that is 5 .

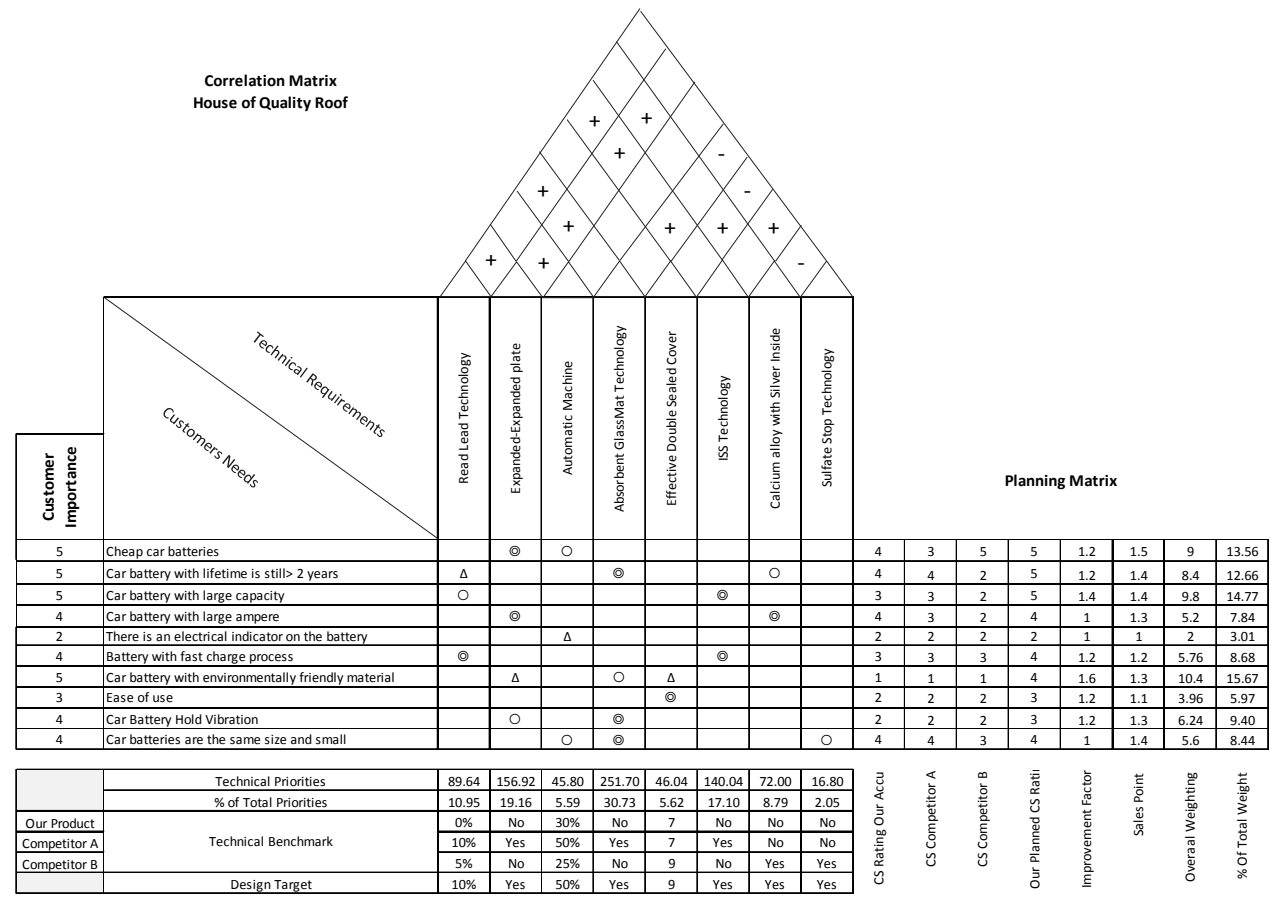

Fig. 3. House of Quality New Product of Maintenance Free Battery

To get the car battery product desired by consumers, it takes technical requirements to achieve it. This technical requirement is attributed to the wishes of the consumer and is scored to see how much the technical terms related to the customer's wish. Rating of the relationship between the customer requirements and the technical requirements was evaluated by a group of product development team. The relationship matrix was then constructed to provide a listing of how the technical requirements represent each customer's needs on a scale of 1,3 , and 9. The rating scale 1 represents a slight or possible relationship, 3 represents a moderate relationship, and 9 stands for a strong relationship. As figure above absorbent glass mat technology and expanded plate technology give a strong relationship with customer needs. Costumer needs in automotive battery products that have good durability with great performance, low price, and environmentally friendly can be achieved by using Glass Mat absorbent technology (AGM) and expanded machine technology. As it is viewed by the relative weight in House of Quality above, absorbent glass mat gets the highest \% of technical priority that is equal to $31 \%$ whereas technology expanded gets the second highest \% of technical priority that is equal to $19 \%$. Because of that, both technologies become the technical priority to develop products in accordance with the wishes of consumers of car battery products that have good durability with great performance and low prices and environmentally friendly. The use of absorbent glass mat (AGM) will make the automotive battery life to be more durable, this is caused by the fact that this type of battery has a separator consisting of fiberglass placed between the plates of the cell that aims to absorb the liquid electrolyte to be stored in the pores-pore fiberglass. It makes the rate of evaporation of the electrolyte very small and anti to the vibration so the plate would not easily fall off when used. Since the internal resistance is very low, the battery will not overheated even if it is used on loads that require large 
currents or when in recharging with high electric current and it can also be stored for a long time without having to re-welded because its self-discharge is very low (1\%-3\% per month). (Self-discharge=decreased capacity/battery voltage under no-load conditions due to internal resistance). Other advantages of using Absorbent Glass Mat include environmentally friendly, maintenance-free car batteries, antievaporation, anti-leak and keep operating even in very cold weather, even though the cracked or broken cracks will still operate properly. The use of expanded technology is closely related to the efficiency of production costs. To make a competitive battery of course one of them is to make battery prices as cheap as possible with good performance.

\section{Conclusion}

In today's global, intense competition and highly competitive market, it is essential for the survival of any organization involved in the business industry to be adaptive, proactive, and responsive to the changes. The parameters of success or failure of a new product in the market depend on how well they meet customers' need and wants. Quality Function Deployment provides a structured methodology for translating the 'Voice of the Customer' into design requirements, guiding the product development process and improving the success rate for new products. In this paper we have explained how QFD improves the maintenance free battery development process by focusing on customer needs and expectations of the customers. Based on House of Quality for developing the new product maintenance free battery, there are two important developments, in the maintenance free battery, life time of battery and performance of battery made according to the customer's expectations. The customer needs and customer wants are identified by market survey. 'Voice of the Customer' is converted from market survey into customer requirements (what's). Product characteristics are developed to achieve the customer needs in technical descriptions (how's). In this case House of Quality is built by developing the relationship between what's and how's.

The result of Quality Function Deployment for maintenance free battery has shown that Absorbent Glass Mat Technology and Plate Expanded Technology had the highest technical priority to meet the customer requirements than others technical requirements. Based on this result, it can be recommended for new development product and will be focused on both technologies above to get the priority customer needs that is car battery products that have good durability with great performance, low prices, and environmentally friendly and can increase the market share and sales volume. The highest customer needs in this paper can be seen at HOQ in customer importance, where the value is 5 from scale 1-5. To meet the customer needs we need technical priority and based on HOQ we can see that absorbent glass mat technology had the highest priority with $\%$ of total priority of $31 \%$ and expanded plate technology had the second highest priority with $\%$ of total priority is $19 \%$.

\section{References}

Benner, M., Linnemann, A. R., Jongen, W. M. F., \& Folstar, P. (2003). Quality Function Deployment (QFD)— can it be used to develop food products? Food Quality and Preference, 14 (4), 327-339.

Boonyanuwat, N., Suthummanon, S., Memongkol, N., \& Chaiprapat, S. (2008). Application of quality function deployment for designing and developing a curriculum for Industrial Engineering at Prince of Songkla University. Songklanakarin Journal of Science \& Technology, 30(3), 349-353

Bui, N., Mattesco, P., Simon P., Steinmetz, J., \& Rocca, E. (1997).The Tin effect in Lead-Calcium alloy. Journal of Power Sources, 67(1-2), 61-67

Chan, L. K., \& Wu, M. L. (2002). Quality function deployment: A literature review. European journal of operational research, 143(3), 463-497.

Carnevalli, J. A., \& Miguel, P. C. (2008). Review, analysis and classification of the literature on QFD-Types of research, difficulties and benefits. International Journal of Production Economics, 114(2), 737-754.

Catherino, H. A., Feres, F. F., \& Trinidad, F. (2004). Sulfation in lead-acid batteries. Journal of Power Sources, 129(1), 113-120. 
Delgado, D. J., \& Aspinwall, E. M. (2003, May). QFD methodology and practical applications-a review. In Proceedings of the Ninth Annual Postgraduate Research Symposium, School of Engineering, The University of Birmingham (pp. 1-5).

Dost, P., \& Sourkounis, C. Nov. 2012. General Realisation Issues of a Battery Management System. In Cyprus: 1st Conference on Power Options for the Eastern Mediterranean Region (POEM) (pp. 147-152).

Endoh, H. (1996). Separators for automotive lead/acid batteries: selection of suitable types for different climate zones. Journal of power sources, 59(1), 51-55.

Fouache, S., Chabrol, A., Fossati, G., Bassini, M., Sainz, M. J., \& Atkins, L. (1999). Effect of calcium, tin and silver contents in the positive grids of automotive batteries with respect to the grid manufacturing process. Journal of power sources, 78(1), 12-22.

Govers, C. P. (2001). QFD not just a tool but a way of quality management. International Journal of Production Economics, 69(2), 151-159.

Hamidullah, R., Akbar, S., Noor, W. (2010). QFD as a tool for improvement of car dashboard. Journal of Quality and Technology Management, 6(1), 1-22.

Islam, R. (2005). Prioritization of ideas in an affinity diagram by the AHP: An example of k-economy. IIUM Journal of Economics and Management, 13(1), 17-18.

Israr,,M., \& Gangele, A. (2014). A quality function development methodology for product development. International Journal of Emerging Trends in Engineering Research, 2(11), 52-63.

Kasim, M.D., Zuhair, A.A., \& Amer, A.M. (2009). An intelligent quality function deployment (IQFD) for manufacturing process environment. Jordan Journal of Mechanical and Industrial Engineering, 3(1), 23-30.

Kerley, R., Hyun, J. H., \& Ha, D. S. (2015, November). Automotive lead-acid battery state-of-health monitoring system. In Industrial Electronics Society, IECON 2015-41st Annual Conference of the IEEE (pp. 003934003938). IEEE.

Natter, M., Mild, A., Feurstein, M., Dorffner, G., \& Taudes, A. (2001). The effect of incentive schemes and organizational arrangements on the new product development process. Management Science, 47(8), 10291045.

Puviyarasu, S.A (2016). An application of quality function development techniques on developing existing product. International Journal of Engineering Trend and Technology, 40(4), 230-235.

Shen, X. X., Tan, K. C., \& Xie, M. (2001). The implementation of quality function deployment based on linguistic data. Journal of Intelligent Manufacturing, 12(1), 65-75.

Homkhiew C, Ratanawilai T, Pochana K, 2012. Application of a quality function deployment technique to design and develop furniture products. Songklanakarin Journal of Science and Technology, 34(6), 663-668.

Partovi, F. Y., \& Corredoira, R. A. (2002). Quality function deployment for the good of soccer. European journal of operational research, 137(3), 642-656.

Dimitrov, M., \& Pavlov, D. (2001). Influence of grid alloy and fast charge on battery cycle life and structure of the positive active mass of lead acid batteries. Journal of power sources, 93(1), 234-257.

Pinta, A. (2002). The improvement of product by using quality function deployment (QFD) technique: a case study of an educational wood toy factory. Master Thesis, King Mongkut Institute of Technology North Bangkok, Bangkok, pp. 68.

Scrosati, B., \& Garche, J. (2010). Lithium batteries: Status, prospects and future. Journal of Power Sources, 195(9), 2419-2430.

Stauss, B. (1993). Service problem deployment: transformation of problem information into problem prevention activities. International Journal of Service Industry Management, 4(2), 41-62.

Thele, M., Karden, E., Surewaard, E., \& Sauer, D. U. (2006). Impedance-based overcharging and gassing model for VRLA/AGM batteries. Journal of Power Sources, 158(2), 953-963.

Vairaktarakis, G. L. (1999). Optimization tools for design and marketing of new/improved products using the house of quality. Journal of Operations Management, 17(6), 645-663.

Yamaguchi, Y., Shiota, M., Nakayama, Y., Hirai, N., \& Hara, S. (2000). In situ analysis of electrochemical reactions at a lead surface in sulfuric acid solution. Journal of Power Sources, 85(1), 22-28.

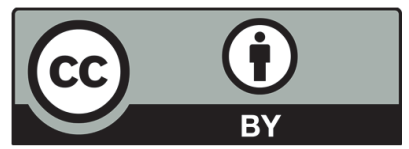

(C) 2017 by the authors; licensee Growing Science, Canada. This is an open access article distributed under the terms and conditions of the Creative Commons Attribution (CC-BY) license (http://creativecommons.org/licenses/by/4.0/). 